\title{
Integrated monitoring and assessment of soil restoration treatments in the Lake Tahoe Basin
}

\author{
M. E. Grismer • C. Schnurrenberger • R. Arst • \\ M. P. Hogan
}

Received: 3 June 2007 / Accepted: 27 February 2008

(C) Springer Science + Business Media B.V. 2008

\begin{abstract}
Revegetation and soil restoration efforts, often associated with erosion control measures on disturbed soils, are rarely monitored or otherwise evaluated in terms of improved hydrologic, much less, ecologic function and longer term sustainability. As in many watersheds, sediment is a key parameter of concern in the Tahoe Basin, particularly fine sediments less than about ten microns. Numerous erosion control measures deployed in the Basin during the past several decades have under-performed, or simply failed after a few years and new soil restoration methods of erosion control are under investigation. We outline a comprehensive, integrated field-based evaluation and assessment of the hydrologic function associated with these soil restoration methods with the hypothesis that restoration of sustainable function will result in longer term erosion control benefits than that currently achieved with more commonly used surface treatment methods (e.g. straw/mulch covers and hydroseeding). The monitoring includes cover-point and ocular assessments of plant cover, species type and diversity; soil sampling for nutrient status; rainfall simulation measurement of infiltration and runoff rates; cone
\end{abstract}

M. E. Grismer $(\bowtie)$

Department of LAWR-Hydrology, UC Davis,

Davis, CA 95616, USA

e-mail: megrismer@ucdavis.edu

C. Schnurrenberger $\cdot$ R. Arst $\cdot$ M. P. Hogan Integrated Environmental Restoration Services, Tahoe City, CA, USA penetrometer measurements of soil compaction and thickness of mulch layer depths. Through multi-year hydrologic and vegetation monitoring at ten sites and 120 plots, we illustrate the results obtained from the integrated monitoring program and describe how it might guide future restoration efforts and monitoring assessments.

Keywords Ecologic function · Erosion ·

Hydrologic function · Monitoring $\cdot$ Runoff $\cdot$ Soils

\section{Introduction}

Development during the past 50 years in the Lake Tahoe Basin has caused an increased flux of sediment and nutrients into the Lake contributing to the loss of Tahoe's exceptional clarity by $25 \%$ from approximately 30 to $21 \mathrm{~m}$. Efforts to slow sediment and nutrient input to the Lake have taken many forms most directed at containment of sediment on-site, or within the drainages from which they originate. Unfortunately, despite considerable effort and resources, little quantitative information exists about the performance of hillslope erosion control measures employed in the basin (Schuster and Grismer 2004; Grismer and Hogan 2005a, b), much less their hydrologic or ecologic function (Cummings 2003). However, there are ample examples of visible erosion control failures as Lake clarity has continued to decline. The recent regulatory efforts associated with 
establishing TMDLs in the basin have refocused land owners towards determining the sources and quantities of sediments and nutrients originating from areas under their management.

Development of skiruns, building and road construction and some forest management practices in the basin all disturb surface soils to varying degrees that may adversely affect subsequent hydrologic function. At worst, nutrient containing topsoil essential for plant growth is removed exposing compacted, readily erodible decomposed granite (DG), or andesitic volcanic subsoils to erosion. As the physico-chemical soil quality declines, vegetation growth is limited and a downward spiral of decreasing ecologic function ensues; infiltration rates decline and erosion rates increase. The thin, poorly developed soils in the basin combined with sub-alpine elevations and dry summers, make abiotic factors and anthropogenic influences particularly damaging to soil quality (Claassen and Hogan 2002). As a result, above and below ground vegetative growth is restricted (Claassen and Zasoski 1998). The low nitrogen availability of volcanic and DG subsoils also limits microbial activity, a critical element in nutrient cycling, soil aggregation and native grass re-establishment. Compounding soil degradation and subsequent lack of plant establishment is the influence of continued erosion on persistent nitrogen deficient soil conditions (Claassen et al. 1995).

\section{Previous work}

While there is an enormous amount of literature related to erosion control in agricultural and relatively humid environments, there are few statistically validated field evaluations of the performance of revegetation/restoration type erosion control efforts in semi-arid, sub-alpine environments (Grismer and Hogan 2004, 2005a, b). Information that is available is often limited to the "grey" literature of "white" papers from agencies, or professional societies. Erosion control work in the Tahoe Basin is not new; White and Franks (1978) documented the near 99\% destruction of stream benthic communities from excessive sediment discharge following development of the Rubicon Properties on the west shore of Lake Tahoe. Subsequent "demonstration" study of various erosion control nettings at Rubicon and Northstar-at-
Tahoe showed decreased erosion rates, but no followup assessment was completed to determine their longer-term viability. Examples of other studies relevant to erosion in the Tahoe Basin include those of Fifield et al. (1988) in the basin and Fifield et al. (1989), Fifield and Malnor (1990), and Fifield (1992a, b) in western Colorado. In these studies, they evaluated the need for irrigation and runoff and erosion from plots "treated" with a variety of "natural" and geotextile covers on $33 \%$ to $67 \%$ slopes. The "natural" treatments included hydroseeding, seed blankets, wood and paper hydromulches, straw, coconut and jute materials. Sediment yields and runoff were measured following natural rainfall events using collection troughs at the base of 24 to $36 \mathrm{~m}^{2}$ plots. Generally, both runoff and sediment yields dramatically decreased as compared to bare soil conditions; sediment yields ranged approximately two orders of magnitude, from 1.0 to $87 \mathrm{~g} \mathrm{~m}^{-2} \mathrm{~mm}^{-1}$ runoff. The established, 2-3 year old dryland grasses on $33 \%$ slopes resulted in a midrange sediment yield of $21 \mathrm{~g} \mathrm{~m}^{-2} \mathrm{~mm}^{-1}$. Standardized or "head-to-head" comparisons of treatment methods were difficult due to differing rainfall intensities (kinetic energies), so averages runoff and erosion values were reported. Not surprisingly, the greatest sediment yield reductions were associated with the largest surface cover biomasses.

Similarly, more recent examples of assessing hydrologic effects of erosion control treatments at higher elevations or in nutrient deficient soils have been reported by Montoro et al. (2000), Poulenard et al. (2001) and Foltz and Copeland (2008). Montoro et al. (2000) described efforts to control erosion from anthropic soils on $40 \%$ slopes using $30 \mathrm{~m}^{2}$ plots treated with vegetal mulch, hydroseeding with added humic acids and hydroseeding with both. Runoff and erosion from natural rainfall events of $2-34 \mathrm{~mm} \mathrm{~h}^{-1}$ were significantly reduced from all treatments as a result of "protection against raindrop impact" and "general improvement in soil structure". As development of grasslands on volcanic ash soils in northern Ecuador resulted in significant soil losses, Poulenard et al. (2001) used simulated rainfall at intensities of 20-120 $\mathrm{mm} \mathrm{h}^{-1}$ for $15 \mathrm{~min}$ on $1 \mathrm{~m}^{2}$ plots to evaluate effects of grassland development, or conversion on soil crusting, infiltration, runoff and erosion rates, but did not include other assessments of the soil. Foltz and Copeland (2008) use a rainfall simulator in the 
laboratory to evaluate sediment yields associated with woodchip coverages of $30 \%, 50 \%$ and $70 \%$ on constructed soil plots of $1.24 \mathrm{~m}$ by $4.0 \mathrm{~m}$ on a $30 \%$ slope. Sediment yield reductions of greater than $60 \%$ as compared to bare soil conditions were obtained and increased with increasing woodchip coverage, but no further measurements were taken. Unfortunately, there were few quantifiable indices used in these studies that could be measures from site to site in a meaningfully comparative manner of soil/plant conditions at the sites and how they may have affected soil function. Grismer et al. (2007) consider some of the variations in treatment efficacy from year-to-year and note that surface treatments generally have little benefit after 2-3 years in terms of reducing erosion rates. Long-term function was also not considered but is crucial towards determining the actual costs associated with sustained erosion control necessary to development of land management strategies needed to meet TMDL requirements. That is, what are the long-term benefits of these erosion control strategies in the field, their transferability to other locations and what effects have they on infiltration rates and soil restoration?

Ellis (2006) reviews rainfall simulation (RS) methods and studies in the Tahoe basin that were used in an attempt to standardize evaluation of soilbased erosion control measures through replicated rainfall events of the same intensity, or kinetic energy on multiple test plots. Grismer and Hogan (2004, 2005a, b) employed the RS on disturbed roadcut and ski run granitic and volcanic soils in the Tahoe Basin to evaluate slope, cover and surface roughness effects on infiltration and runoff rates and runoff sediment concentration (SC) and sediment yield (SY). They determined that plot microtopography or roughness and cross-slope had no effect on runoff SCs or SYs. Grismer and Hogan (2004) found that runoff rates, SCs and SYs were greater from volcanic soils as compared to that from granitic soils for nearly all cover conditions. RS measured runoff rates and sediment yields from the bare soils were significantly correlated with downslope. SYs from bare granitic soils at slopes of $28 \%$ to $78 \%$ ranged from $\sim 1-12 \mathrm{~g} \mathrm{~m}^{-2} \mathrm{~mm}^{-1}$ of runoff, respectively, while from bare volcanic soils at slopes of $22-61 \%$ ranged from $\sim 3-31 \mathrm{~g} \mathrm{~m}^{-2} \mathrm{~mm}^{-1}$, respectively (Grismer and Hogan 2005a). Further, volcanic ski run soils and both ypes of road cut soils exhibited nearly an order of magnitude greater SY than that from the corresponding "native", relatively undisturbed sites. Similarly, the granitic ski run soils produced nearly four times greater SC than the native areas. Revegetation, or application of pine needle mulch (PNM) covers to both soil types decreased SCs and SYs by 30-50\%. Soil restoration through incorporation of woodchips, or tillage and use of amendments (e.g. Biosol ${ }^{\circledR}$, compost) and mulch covers together with plant seeding resulted in little, or no runoff (or SY) from either soil regardless of rainfall intensity. In a preliminary study, Grismer and Ellis (2006) examined the particle-size distributions (PSDs) associated with runoff sediment from the RS studies begun by Grismer and Hogan (2004) that are considered with greater rigor and detail by Grismer et al. (2007).

\section{Research objectives}

Overall, we hypothesized that soil rehabilitation and native grass revegetation will be reflected in greater infiltration rates and less runoff or sediment yield in successfully restored sites and that these changes can be measured directly in the field. Here we consider evaluation plant, soil and hydrologic factors associated with a variety of soil revegetation/cover treatments on road cuts and ski runs of varying slopes and subsequent comparison to that from bare and "native" soils as described in Grismer and Hogan (2005b). We use these various treatment sites as they reflect a "gradient" of relative soil function between bare disturbed soils to relatively high functioning "native" soils. In forest and shrub "native" soils, mulch provides much of the soil nutrient input the remaining coming from root material, microbes, other soil macrofauna and flora and some from the atmosphere. In addition, mulch attenuates soil surface temperatures and evaporation. Time is an important component in developing the assessment strategy as mulch replacement and turnover rates depend partially on the type and amount of vegetation present such that mulch can integrate the plant component of a restoration project.

This paper describes the monitoring results from nine treated sites and several native sites throughout the Tahoe-Truckee area (Table 1). The objective of these study plots was to investigate how each 
Table 1 Soil restoration monitoring sites in Tahoe Basin

\begin{tabular}{|c|c|c|c|c|c|}
\hline Site description & Year established & Soil type & Elevation (m) & Slope $(\%) /$ aspect & Foliar cover $(\%)$ \\
\hline Brockway test plots & 2005 & Volcanic & 2125 & 50/WSW & 19 \\
\hline Brockway fill slopes & 2004 & Volcanic & 2131 & $56 / \mathrm{S}$ & 19 \\
\hline Northstar Unit 7 & 2001 & Volcanic & 1982 & $60 / \mathrm{N}$ & 35 \\
\hline Northstar LT plots & 2003 & Volcanic & 2049 & $55 / \mathrm{NW}$ & $56^{\mathrm{a}}$ \\
\hline Resort at Squaw Creek & 2002 & Volcanic & 2103 & $42 / \mathrm{NW}$ & 31 \\
\hline Truckee Bypass plots & 2005 & Volcanic & 1758 & $50 / \mathrm{NE}$ & 26 \\
\hline Tahoma Boxes-Volc & 2003 & Volcanic & 1920 & NA & $61^{\mathrm{a}}$ \\
\hline Heavenly LT plots & 2003 & Granitic & 2610 & $35 / \mathrm{N}$ & $41^{\mathrm{a}}$ \\
\hline Meyers Airport & 2004 & Granitic & 1912 & $53 / \mathrm{E}$ & 8 \\
\hline Tahoma Boxes-Gran & 2003 & Granitic & 1920 & NA & 47 \\
\hline
\end{tabular}

${ }^{\mathrm{a}}$ Ocular estimates

component of restoration (soil loosening, seed rate, incorporation of amendments, and addition of fertilizer and surface mulch) affected erosion control by increasing onsite infiltration and reducing sediment production and movement. The effectiveness of treatments was measured directly using RS techniques to determine infiltration rates and sediment yields; some RS results for several years are considered and have been described previously (Grismer and Hogan 2005b; Grismer et al. 2007). The RS results were then compared to measurements of soil density, plant cover (type and diversity), soil moisture, soil nutrient levels (OM\%, TKN, C:N ratio) and ground cover by mulch to determine the relationship between these site parameters and erosion control.

\section{Methodology}

Tables 1 and 2 summarize basic information about the monitoring locations and the erosion control treatments deployed, respectively, considered here. Table 3

Table 2 Soil treatments employed at each location

\begin{tabular}{|c|c|c|c|c|c|}
\hline Site description & Cover & $\begin{array}{l}\text { Grass } \\
\text { species }\end{array}$ & Amendments & Incorporation? & Comments \\
\hline Brockway Fill Plots & $\begin{array}{l}\text { None or } 25 \mathrm{~mm} \\
\text { PNM }\end{array}$ & Native mix & Compost/Biosol $@$ & $\begin{array}{l}\text { None or Tilled } \\
\sim 0.37 \mathrm{~m}\end{array}$ & $\begin{array}{l}\text { Re-treatment after failures in } \\
2004\end{array}$ \\
\hline Brockway test slopes & $\begin{array}{l}\text { None or } 37 \mathrm{~mm} \\
\text { PNM }\end{array}$ & Native mix & Compost/Bio/WC & $\begin{array}{l}\text { None or Tilled } \\
\sim 0.37 \mathrm{~m}\end{array}$ & $\begin{array}{l}1998 \text { plots tilled and amends } \\
\text { added }\end{array}$ \\
\hline Northstar LT plots & $\begin{array}{l}\text { None or } 37 \mathrm{~mm} \\
\text { PNM }\end{array}$ & Native mix & Compost/Bio/WC & $\begin{array}{l}\text { None or Tilled } \\
\sim 0.37 \mathrm{~m}\end{array}$ & $\begin{array}{l}\text { Long-term test plots on lower } \\
\text { skirun }\end{array}$ \\
\hline Northstar U7 plots & $51 \mathrm{~mm}$ PNM & Native mix & Compost/Biosol $\subset$ & Tilled $\sim 0.25 \mathrm{~m}$ & $\begin{array}{l}\text { Roadcut study to compare with } \\
\text { Std. hydroseeding }\end{array}$ \\
\hline $\begin{array}{l}\text { Resort at Squaw } \\
\text { Creek }\end{array}$ & $\begin{array}{l}\text { None or } 37 \mathrm{~mm} \\
\text { PNM }\end{array}$ & Native mix & Compost/WC & $\begin{array}{l}\text { None or Tilled } \\
\sim 0.37 \mathrm{~m}\end{array}$ & $\begin{array}{l}\text { Skirun study to compare with } \\
\text { Std. trmt., hydroseeding }\end{array}$ \\
\hline Truckee Bypass Plots & $\begin{array}{l}\text { None or } 37 \mathrm{~mm} \\
\text { PNM }\end{array}$ & Native mix & Compost/Bio/WC & $\begin{array}{l}\text { Ripped/Tilled } \\
\sim 0.46 \mathrm{~m}\end{array}$ & $\begin{array}{l}\text { Roadcut test area to compare } \\
\text { w/ Std. trmt }\end{array}$ \\
\hline Tahoma Boxes-Volc & $\begin{array}{l}\text { None or } 37 \mathrm{~mm} \\
\text { PNM }\end{array}$ & Native mix & Compost/Bio/WC & NA & $\begin{array}{l}\text { Study boxes to examine soil } \\
\text { function }\end{array}$ \\
\hline Heavenly LT plots & $\begin{array}{l}\text { None or } 37 \mathrm{~mm} \\
\text { PNM }\end{array}$ & Native mix & Compost/Bio/WC & $\begin{array}{l}\text { None or Tilled } \\
\sim 0.37 \mathrm{~m}\end{array}$ & $\begin{array}{l}\text { Long-term test plots on lower } \\
\text { skirun }\end{array}$ \\
\hline Meyers Airport & PNM or WC & Native mix & Compost/Bio/WC & $\begin{array}{l}\text { None, Rip or } \\
\text { Tilled } \sim 0.37 \mathrm{~m}\end{array}$ & $\begin{array}{l}\text { Long-term test plots on problem } \\
\text { roadcut }\end{array}$ \\
\hline Tahoma Boxes-Gran & $\begin{array}{l}\text { None or } 37 \mathrm{~mm} \\
\text { PNM }\end{array}$ & Native mix & Compost/Bio/WC & NA & $\begin{array}{l}\text { Study boxes to examine soil } \\
\text { function }\end{array}$ \\
\hline
\end{tabular}


Table 3 Native grass seeds used in mixtures applied at treatment locations

\begin{tabular}{ll}
\hline Common name & Scientific name \\
\hline Mountain brome & Bromus carinatus \\
Squirreltail & Elymus elymoides \\
Yarrow & Achillea millefolium \\
Western needlegrass & Achnatherum occidentale \\
Sagebrush & Artemisia tridentata \\
Rabbitbrush & Chrysothamnus nauseosus \\
Elongated hairgrass & Deschampsia elongata \\
Nude buckwheat & Eriogonum nudum \\
Spanish lotus & Lotus purshianus \\
Gray's lupine & Lupinus grayii \\
Brewer's lupine & Lupinus breweri \\
\hline
\end{tabular}

outlines the native grass seeds employed in mixtures used in seeding many of the plots. All of the monitoring methods deployed in this study have been developed and described elsewhere (Caltrans 2007) and are outlined below.

\section{Cover conditions}

Plant and mulch cover was measured using the coverpoint method along randomly located transects, (Elzinga et al. 2001; Hogan 2003). Two cover measurements were recorded, (a) the first hit cover, which represents the first object intercepted starting from a height of $1 \mathrm{~m}$ above the ground, and (b) the ground cover hit. The first hit cover measures the foliar cover by plants (leaves and stems). It does not measure the part of the plant actually rooted in the ground. The ground cover hit measures whatever is lying on the ground or rooted in the ground (i.e., litter/mulch, bare ground, basal (or rooted) plant cover, rock and woody debris). Total ground cover represents any cover other than bare ground. Plant cover, both ground and foliar, was recorded by species and then organized into cover groups based on the lifeform and longevity of the plant. Perennial herbaceous species include seeded grasses, native grasses, forbs and any nonnative perennial species. Annual herbaceous species include invasive species such as cheatgrass (Bromus tectorum). Woody species are tree and shrub species of interest whether native or introduced. Species of interest include species that were seeded, and problem species, such as alien invasive plants.

\section{Soil conditions}

Soil compaction and soil moisture were measured along the same transects as the cover-point data for all plots. A cone penetrometer with a $1 / 2$ in. (12.7 mm) diameter tip was used to measure soil compaction along transects and around the RS plots. The penetrometer was pushed vertically into the soil until a maximum pressure, or resistance of $2,411 \mathrm{kPa}$ was reached, and this depth was noted as the depth to refusal (DTR). (In the rainfall simulation plots, the penetrometer resistance for DTR was recorded at 1,722 $\mathrm{kPa}$.) We anticipate standardizing these measurements in the future and use them as an index for infiltration capacity (e.g. Hatchett et al. 2006). A handheld Time Domain Reflectometer (TDR) hydrometer was used to measure volumetric soil moisture content adjacent to the penetrometer readings as well as in the rainfall simulation plots (prior to rainfall) at a depth of $120 \mathrm{~mm}$. Solar input was determined using a Solar Pathfinder. Since solar input affects evaporation rates and soil temperature, which may affect time of seed germination, germination rate, rate of plant growth and soil microbial activity, it is an important variable to consider when monitoring plant growth and soil development.

Soil sub-samples were taken from beneath the mulch layer (if present) to a depth of $0.3 \mathrm{~m}$ at each plot, combined for the location and then sieved to remove any material larger than $2 \mathrm{~mm}$, and sent in for standard laboratory analyses. Analyses included organic matter (OM), total Kjeldahl nitrogen (TKN), phosphorus (Weak Bray and Sodium Bicarbonate-P), extractable cations (potassium, magnesium, calcium, sodium), hydrogen, sulfate- $\mathrm{S}, \mathrm{pH}$, cation exchange capacity (CEC), nitrate-nitrogen, zinc, manganese, iron, copper and boron, soluble salts, and excess lime. Generally, disturbed basin soils are very deficient in nitrogen (Claassen and Hogan 2002).

\section{Rainfall simulation plots}

Rainfall simulation (RS) techniques described by Grismer and Hogan (2004) were employed to determine infiltration, runoff and erosion (sediment yield) rates from the $1 \mathrm{~m}^{2}$ plots at each location. Simulated rainfall intensities of $60-120 \mathrm{~mm} / \mathrm{h}$ were used. Briefly, the portable drop-former type rainfall simulator "rains" from a height of $1 \mathrm{~m}$, a steady rainfall 
rate is maintained and the time to runoff (if any) is recorded when water first passes over the metal plot frame lip into a collection trough. Runoff is collected in $175 \mathrm{ml}$ plastic bottles and the time required to fill each bottle is noted. Runoff collection continues until a steady runoff rate is observed or $30-40 \mathrm{~min}$ of rainfall has elapsed. The infiltration rate is calculated by difference using the rainfall and runoff rates. The collected runoff samples are then filtered to determine the amounts of sediment and organic matter in the runoff as well as calculating the plot sediment yield (erodibility) Depending on the runoff variability at each location, typically three RS plot tests were conducted per treatment.

Statistical comparison of results between treatments at the different sites included the Tukey and Student " $t$ " tests and ANOVA based methods using $F$ and $P$ values to assess differences at the $95-99 \%$ confidence levels.
The broad monitoring and assessment at the ten different locations considered here builds on previous runoff and erosion assessments in the Tahoe Basin described by Grismer and Hogan (2004, 2005a, b), Grismer and Ellis (2006), Grismer (2007) and Hatchett et al. (2006). As the breadth of material considered is quite large, we limit our detailed results presentation here to the Northstar and Heavenly longterm (LT) sites. These two sites represent the volcanic and granitic soil types found in the Tahoe Basin as well as encompassing the range and history of treatments encountered at all of the sites. Integrated measurements continue at these sites every summer season through 2010.

The Northstar and Heavenly LT sites each consist of 23 treated plots and four control plots built in 2003 (Figs. 1 and 2). All of the plots are $3 \times 3 \mathrm{~m}$ with $1 \mathrm{~m}$ buffer areas on all sides. The plot layout and treatments are shown in Fig. 1. For simplicity, only
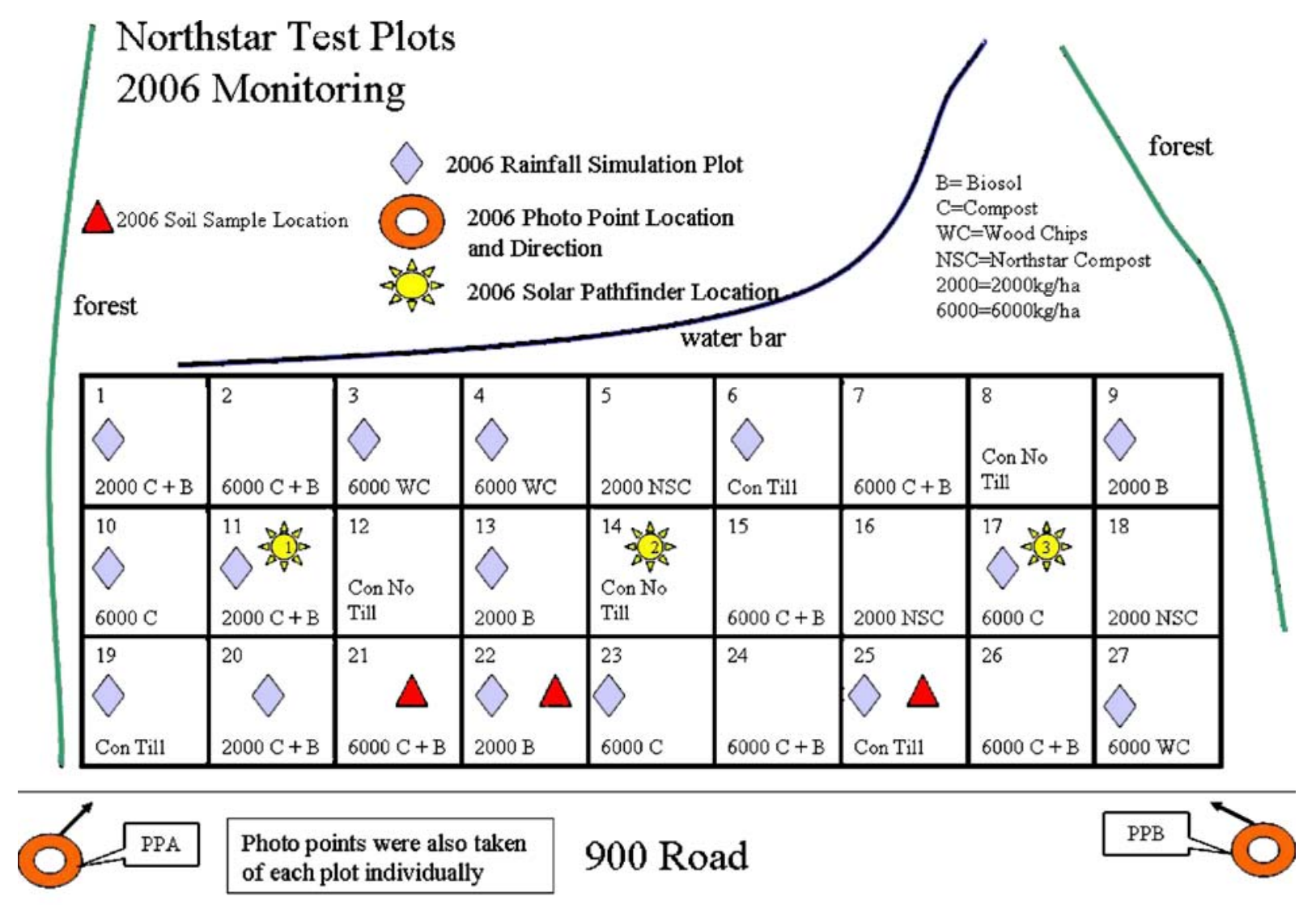

\section{Road}

turnout/parking

Fig. 1 Northstar LT test plots treatment matrix and 2006 sampling points 


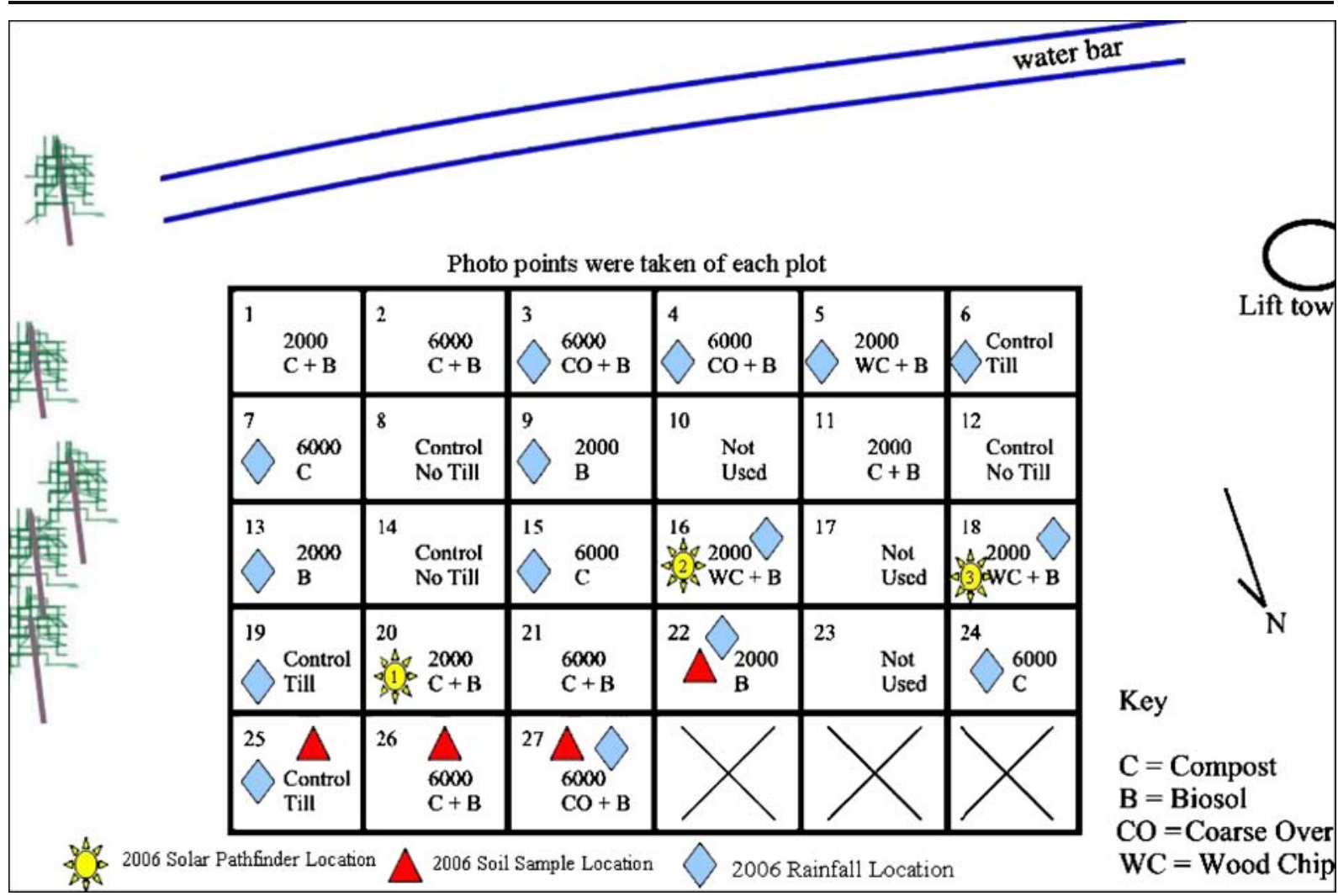

Fig. 2 Heavenly LT test plots treatment matrix and 2006 sampling points

the rainfall simulation locations for 2006 are shown in Figs. 1 and 2, though simulations have been conducted on all the plots during previous summers of 2004 and 2005. The plots were installed at the bottom of ski runs having mid-mountain fire road access. Both sites had received rough grading in the past with removal of tree stumps and rocks. Prior revegetation treatments were not applied to the area, but intermediate wheatgrass and orchard grass, both used in nearby erosion control projects, were present at the site. The treatment variables involved tilling versus no tilling, Biosol fertilizer rate, and amendment type (compost versus composted woodchips). The soils at the site had on average of $50 \%$ coarse material $(>12.7 \mathrm{~mm}$ diameter). Prior to treatment, the area was mostly covered with intermediate wheatgrass and orchard grass, both perennial species often used in revegetation. Despite this plant cover, sheet erosion and rills were amply evident.

Three different types of compost, applied at two different rates, were used at this site. Compost was applied at nitrogen $(\mathrm{N})$ equivalent rates of 2,000 and $6,000 \mathrm{~kg} \mathrm{~N} / \mathrm{ha}$ using a Gradall reach forklift equipped with a loading bucket prior to tilling the soil. Following compost application, plots were tilled to a depth of at least $0.3 \mathrm{~m}$ using a Woods backhoe attached to a Kubota 3830 tractor. Biosol organic fertilizer, which has a 6-1-3 nitrogen-phosphorouspotassium ratio, was applied on specific plots at a nitrogen equivalent rate of $120 \mathrm{~kg} \mathrm{~N} / \mathrm{ha}$, or a bulk rate of $2,000 \mathrm{~kg}$ Biosol/ha. The Biosol was hand applied after each plot was tilled and then raked into the soil surface to a depth of $25 \mathrm{~mm}$. All treatment areas received a native grass seed mix at the rate of $140 \mathrm{~kg} / \mathrm{ha}$. The seed was lightly raked into the soil surface after application to ensure adequate soil contact. Approximately $30 \mathrm{~m}^{3}$ of pine needles were used to mulch the test plots. A Shred-Vac mulch blower was used to apply the pine needle mulch to the entire treatment area to a thickness of approximately $37 \mathrm{~mm}$. After the pine needle mulch was applied, a paddle agitator-equipped hydroseeder was then used to apply tackifier across the treatment area.

Prior to treatment in at each site, nine soil samples were collected from throughout the treated area and from three reference sites on the sides of the ski run. 
Pre-treatment data collected includes soil moisture, soil compaction, and solar radiation.

\section{Results and discussion-LT sites}

Results from the Northstar and Heavenly long-term monitoring sites are considered in detail to illustrate the integrated monitoring and assessment developed here followed by a more general discussion of the implications of the monitoring observations from all ten sites. The two LT sites were identical in design and are excellent examples of the longer-term integrated monitoring and assessment we suggest as crucial towards land restoration efforts. The broad range of assessments at each site is important towards developing possible restoration strategies that are, or will be effective in the Tahoe Basin. As the restoration hydrologic response is the key quantitative description of the relative restoration success, we consider the RS results first followed by the soils and plant monitoring and analyses results.

Tables 4 and 5 summarize the primary results of the RS tests conducted at the Northstar and Heavenly LT sites for the years 2004-2006, respectively. Each row of results represents the average of three RS tests per treatment, or approximately $60 \mathrm{RS}$ tests per site per year (with the exception of the CT treatment tests only conducted the first year after plot installation). At both sites, very limited, or no runoff was obtained from several RS tests each year as reflected in the very high infiltration rates. With very limited runoff samples, there was insufficient sample for particlesize analyses. Generally, increasing levels of treatment resulted in progressively increasing infiltration rates or cone penetrometer (CP) depths and decreasing sediment yields (SY) or erodibilities. Runoff from the more heavily treated plots also had somewhat larger particle-sizes and not surprisingly greater organic matter contents. Note that the particle-sizes

Table 4 RS test results from Northstar LT plots for 2004-2006

\begin{tabular}{|c|c|c|c|c|c|c|c|c|c|c|c|c|c|c|}
\hline \multirow[t]{2}{*}{ Treatment } & \multirow[t]{2}{*}{ Year } & \multirow[t]{2}{*}{$\begin{array}{l}\text { Infiltration } \\
(\mathrm{mm} / \mathrm{h})\end{array}$} & \multirow[t]{2}{*}{$\begin{array}{l}\text { Runoff } \\
(\mathrm{mm} / \mathrm{h})\end{array}$} & \multirow[t]{2}{*}{$\begin{array}{l}\mathrm{CP} \\
(\mathrm{mm})\end{array}$} & \multirow[t]{2}{*}{$\begin{array}{l}\mathrm{SC} \\
(\mathrm{g} / \mathrm{l})\end{array}$} & \multirow[t]{2}{*}{$\begin{array}{l}\mathrm{OM} \\
(\%)\end{array}$} & \multirow[t]{2}{*}{$\begin{array}{l}\text { SY } \\
(\mathrm{g} / \mathrm{mm})\end{array}$} & \multicolumn{4}{|c|}{$\begin{array}{l}\text { Runoff particle-size } \\
\text { distribution }(\mathrm{mm})\end{array}$} & \multicolumn{3}{|c|}{ Soil texture } \\
\hline & & & & & & & & $D_{10}$ & $D_{30}$ & $D_{60}$ & $D_{90}$ & $\begin{array}{l}\% \\
\text { Clay }\end{array}$ & $\begin{array}{l}\% \\
\text { Silt }\end{array}$ & $\begin{array}{l}\% \\
\text { Sand }\end{array}$ \\
\hline Control no-till & 2004 & 69.95 & 2.03 & 25 & 0.58 & 7.15 & 0.27 & 5.30 & 16.70 & 40.65 & 154.0 & 5.60 & 59.70 & 34.70 \\
\hline \multirow[t]{3}{*}{ Control till } & 2004 & 48.41 & 24.59 & 70 & 0.08 & 11.88 & 0.16 & & & & & & & \\
\hline & 2005 & 55.91 & 19.09 & 60 & 0.23 & 13.92 & 0.26 & 4.10 & 15.06 & 55.88 & 353.0 & 6.10 & 55.85 & 38.05 \\
\hline & 2006 & 71.67 & 6.33 & 55 & 0.12 & 12.34 & 0.14 & & & & & & & \\
\hline Average CT & & 58.66 & 16.67 & 62 & 0.14 & 12.71 & 0.19 & & & & & & & \\
\hline \multirow[t]{3}{*}{2000 Biosol (B) } & 2004 & 65.09 & 5.28 & 55 & 0.08 & 15.80 & 0.16 & & & & & & & \\
\hline & 2005 & $>120$ & 0.00 & 50 & 0.00 & & 0.00 & 7.19 & 22.53 & 84.75 & 622.8 & 5.05 & 47.78 & 47.18 \\
\hline & 2006 & 62.21 & 9.79 & 45 & 0.08 & 12.68 & 0.08 & & & & & & & \\
\hline Average Biosol & & 82.43 & 5.02 & 50 & 0.05 & 14.24 & 0.08 & & & & & & & \\
\hline \multirow[t]{2}{*}{6000 compost $(\mathrm{C})$} & 2004-2005 & $>120$ & 0.00 & 55 & 0.00 & 0.00 & 0.00 & & & & & & & \\
\hline & 2006 & 98.65 & 21.35 & 47 & 0.04 & 56.56 & 0.03 & 3.65 & 12.90 & 35.03 & 257.5 & 6.58 & 62.40 & 31.02 \\
\hline Average comp & & 109.33 & 10.67 & 51 & 0.02 & 28.28 & 0.02 & & & & & & & \\
\hline \multirow[t]{3}{*}{$2000 \mathrm{C}+\mathrm{B}$} & 2004 & $>120$ & 0.00 & 88 & 0.00 & 0.00 & 0.00 & & & & & & & \\
\hline & 2005 & 102.36 & 22.64 & 80 & 0.10 & 18.56 & 0.15 & 7.62 & 29.60 & 94.85 & 673.5 & 3.77 & 38.54 & 57.70 \\
\hline & 2006 & 107.42 & 12.58 & 60 & 0.19 & 49.65 & 0.16 & & & & & & & \\
\hline Average $\mathrm{C}+\mathrm{B}$ & & 109.93 & 11.74 & 75 & 0.10 & 22.74 & 0.11 & & & & & & & \\
\hline \multirow[t]{2}{*}{$2000 \mathrm{WC}+\mathrm{B}$} & $2004-5$ & $>120$ & 0.00 & 110 & 0.00 & & 0.00 & & & & & & & \\
\hline & 2006 & 107.59 & 12.41 & 80 & 0.09 & 20.62 & 0.07 & & & & & & & \\
\hline Average WC + B & & 113.80 & 6.20 & 95 & 0.04 & 20.62 & 0.04 & & & & & & & \\
\hline \multirow[t]{2}{*}{ Natives } & 2005 & 115.01 & 5.99 & 124 & 0.27 & 36.40 & 0.26 & & & & & & & \\
\hline & 2006 & 117.00 & 3.00 & 150 & 0.03 & 32.63 & 0.02 & & & & & & & \\
\hline Average natives & & 116.00 & 4.50 & 137 & 0.15 & 34.52 & 0.14 & & & & & & & \\
\hline
\end{tabular}


Table 5 RS test results from Heavenly LT plots for 2004-2006

\begin{tabular}{|c|c|c|c|c|c|c|c|c|c|c|c|c|c|}
\hline \multirow[t]{2}{*}{ Treatment } & \multirow[t]{2}{*}{ Year } & \multirow[t]{2}{*}{$\begin{array}{l}\text { Infiltration } \\
(\mathrm{mm} / \mathrm{h})\end{array}$} & \multirow[t]{2}{*}{$\begin{array}{l}\text { Runoff } \\
(\mathrm{mm} / \mathrm{h})\end{array}$} & \multirow[t]{2}{*}{$\begin{array}{l}\mathrm{SC} \\
(\mathrm{g} / \mathrm{l})\end{array}$} & \multirow[t]{2}{*}{$\begin{array}{l}\mathrm{OM} \\
(\%)\end{array}$} & \multirow[t]{2}{*}{$\begin{array}{l}\mathrm{SY} \\
(\mathrm{g} / \mathrm{mm})\end{array}$} & \multicolumn{4}{|c|}{$\begin{array}{l}\text { Runoff particle-size } \\
\text { distribution }(\mathrm{mm})\end{array}$} & \multicolumn{3}{|c|}{ Soil texture } \\
\hline & & & & & & & $D_{10}$ & $D_{30}$ & $D_{60}$ & $D_{90}$ & $\begin{array}{l}\% \\
\text { Clay }\end{array}$ & $\begin{array}{l}\% \\
\text { Silt }\end{array}$ & $\begin{array}{l}\% \\
\text { Sand }\end{array}$ \\
\hline Control no-till & 2004 & 101.3 & 6.24 & 0.010 & 20.0 & 0.010 & & & & & & & \\
\hline \multirow[t]{3}{*}{ Control till } & 2004 & 105.5 & 7.25 & 0.037 & 11.8 & 0.092 & & & & & & & \\
\hline & 2005 & 93.74 & 26.26 & 0.235 & 10.1 & 0.309 & 17.58 & 76.22 & 355.17 & 1034.67 & 1.92 & 22.90 & 75.18 \\
\hline & 2006 & 79.89 & 4.11 & 0.034 & 19.5 & 0.127 & & & & & & & \\
\hline Average CT & & 93.04 & 12.54 & 0.10 & 13.81 & 0.18 & & & & & & & \\
\hline \multirow[t]{2}{*}{2000 Biosol (B) } & 2005 & 116.9 & 3.08 & 0.072 & 5.58 & 0.253 & 13.10 & 43.10 & 119.0 & 463.0 & 2.11 & 31.99 & 65.90 \\
\hline & 2006 & $>120$ & 0 & 0 & & 0 & & & & & & & \\
\hline Average Biosol & & 118.46 & 1.54 & 0.04 & 5.58 & 0.13 & & & & & & & \\
\hline \multirow[t]{2}{*}{6000 compost $(\mathrm{C})$} & 2004 & 64.03 & 5.98 & 0.144 & 10.0 & 0.258 & & & & & & & \\
\hline & $2005-6$ & $>120$ & 0 & 0 & & 0 & & & & & & & \\
\hline Average Comp & & 101.34 & 1.99 & 0.05 & 10.00 & 0.09 & & & & & & & \\
\hline $6000 \mathrm{C}+\mathrm{B}$ & $2004-6$ & $>120$ & 0 & 0 & 0 & 0 & & & & & & & \\
\hline $2000 \mathrm{WC}+\mathrm{B}$ & $2004-6$ & $>120$ & 0 & 0 & 0 & 0 & & & & & & & \\
\hline Natives & 2005 & 98.37 & 21.63 & 0.222 & 49.0 & 0.199 & & & & & & & \\
\hline
\end{tabular}

in runoff form the granitic soils at Heavenly are more than twice that from Northstar. RS tests conducted on "native" (relatively undisturbed forest soils adjacent to the LT site plots) usually resulted in no runoff as a result of very high infiltration rates, but runoff that was obtained contained the highest OM contents. It should be noted that SYs from both sites are very small (five to ten times less) relative to that of disturbed soil sites elsewhere in the basin (Grismer and Hogan 2005b).

Previous work has shown that sediment yield is often lower from plots with greater perennial grass and mulch cover other factors being equal (Grismer and Hogan 2004); however, at the Northstar test plots, there was a much better relationship with perennial plant cover than with mulch cover. The plots with the highest sediment yield had similar mulch cover to other treatment plots and a lower estimate of perennial plant cover, particularly cover by the seeded grass species (see Table 6). The estimated mulch cover at the Northstar and Heavenly LT plots was low (50$80 \%$ ) as compared to estimates at other sites, perhaps as a result of mulch movement downhill after initial placement. Other test sites with higher ground cover by mulch were generally installed less than 2 years ago. The depth at which mulch is applied may also affect the long term persistence of mulch cover. Mulch at more recent sites has been applied to depths of at least $50 \mathrm{~mm}$ while at the Northstar and Heavenly LT plots, mulch was applied at a depth of only $38 \mathrm{~mm}$.

Not surprisingly, most foliar cover was by perennial native species at both LT sites. Perennial grass cover was lowest on the control plots (Tables 6,7 and 8 ) and standard deviations were fairly large for all treatments except control no-till. Using the Tukey test, the only plots showing statistically greater (at $>95 \%$ level) perennial cover than the control plots were those with $6,000 \mathrm{~kg} \mathrm{~N} / \mathrm{ha}$ of compost or compost plus Biosol. Plots with Biosol only or Biosol and $2,000 \mathrm{~kg} \mathrm{~N} / \mathrm{ha}$ of compost had greater average cover but the differences were not significant. The mean solar radiation, or solar exposure, at the Northstar site is $93 \%$, suggesting that sunlight is not limited at the site and may actually be excessive. Similarly, the mean solar radiation at the Heavenly LT plots was $85 \%$, ranging between $78 \%$ and $91 \%$ across the plots. Plots near the trees received more shade and had lower solar exposure. This may have had a small affect on plant growth, species composition and soil moisture, but no pattern was detected during the cover sampling at either site. With solar radiation greater than $85 \%$, sunlight would not be limiting and conditions would support more xeric plant species such as western needlegrass and squirreltail. This high solar radiation and the lower nutrient levels found in 
Table 6 Herbaceous cover and type (\%) in 2006 as affected by treatment at Northstar LT plots

\begin{tabular}{|c|c|c|c|c|c|c|c|}
\hline \multirow[t]{2}{*}{ Treatment } & \multicolumn{2}{|c|}{ Total foliar cover } & \multirow[t]{2}{*}{ Annual grasses } & \multirow[t]{2}{*}{ Perennial grass } & \multirow[t]{2}{*}{ Perennial woody } & \multirow[t]{2}{*}{ Non-native } & \multirow{2}{*}{$\frac{2006 \mathrm{PN}}{\text { Mulch }}$} \\
\hline & Percent & $\mathrm{SD}$ & & & & & \\
\hline Control NT & 50 & 6 & 5 & 30 & 0 & 15 & ND \\
\hline Control till & 40 & 24 & 1 & 29 & 1 & 9 & 78 \\
\hline $2000 \mathrm{~B}$ & 73 & 23 & 7 & 61 & 0 & 5 & 57 \\
\hline $2000 \mathrm{C}+\mathrm{B}$ & 75 & 13 & 1 & 51 & 1 & 22 & 67 \\
\hline $6000 \mathrm{C}$ & 86 & 12 & 1 & 63 & 0 & 22 & 71 \\
\hline $6000 \mathrm{C}+\mathrm{B}$ & 79 & 20 & 1 & 64 & 1 & 13 & ND \\
\hline $6000 \mathrm{WC}$ & 86 & 22 & 21 & 50 & 1 & 14 & 74 \\
\hline Native & 64 & NA & 0 & 32 & 32 & 0 & 93 \\
\hline
\end{tabular}

the granitic soils at Heavenly may account for the lower cover by mountain brome and lack of cover by blue wild-rye, both of which are more common in more shaded areas.

Most plant cover at the Heavenly LT site was perennial species, though some plots had up to $30 \%$ cover by native annuals. While cover by annual species can be helpful towards reducing erosion, we focus here on the perennial species as annual species have very shallow root systems that have not exhibited an effect on soil strength (Goldsmith 2006). Invasive or noxious weeds were not found at the Heavenly site, most likely because of the high elevation and remote location. In general, the treatments with higher and more consistent cover by perennial species also had higher cover by the seeded species. On average, the seeded species made up from $39 \%$ to $82 \%$ of the perennial plants observed. The majority of native species are forbs, not grasses, which in general, do not have as extensive a root system as grasses. The bunchgrasses planted at the Heavenly site have extensive root systems and were

Table 7 Perennial grass and mulch cover (\%) in 2006 as affected by treatment at Heavenly LT plots

\begin{tabular}{|c|c|c|c|}
\hline \multirow[t]{2}{*}{ Treatment } & \multicolumn{2}{|c|}{ Perennial cover } & \multirow{2}{*}{$\frac{2006 \mathrm{PN}}{\text { Mulch }}$} \\
\hline & Percent & SD & \\
\hline Control NT & 46 & 34 & 80 \\
\hline Control till & 78 & 13 & 75 \\
\hline $2000 \mathrm{~B}$ & 74 & 36 & 63 \\
\hline $2000 \mathrm{C}+\mathrm{B}$ & 65 & 15 & 75 \\
\hline $6000 \mathrm{C}$ & 39 & 12 & 55 \\
\hline $6000 \mathrm{C}+\mathrm{B}$ & 66 & 16 & 77 \\
\hline $6000 \mathrm{WC}$ & 82 & 14 & 53 \\
\hline
\end{tabular}

selected to improve soil strength, while maintaining lower soil density. A desired outcome is to increase the relative cover by these seeded species; therefore, cover by seeded species is discussed below. The treatments that had the highest and most consistent cover by seeded perennial grasses were those with woodchips or coarse-overs as amendments, and the plots with 2,000 kg N/ha compost and Biosol. The woodchips and coarse-overs plots also had some of the highest infiltration rates and no runoff. Presently, after 3 years, greater establishment and cover by seeded perennial grasses in plots with compost added. It could be that over time the nitrogen held within the woodchips and coarse-overs is released as the material decomposes. Similar results were obtained at the Northstar LT site where cover by perennial species was similar between plots with compost and woodchips after three growing seasons. Western needlegrass comprised most of the cover by seeded species under most treatment conditions. [This species was not dominant at the other sites, perhaps as a result of soils of volcanic origin. Western needlegrass may

Table 8 Cone penetrometer (CP) measurements as affected by Treatment and soil moisture

\begin{tabular}{llll}
\hline Treatment & \multicolumn{2}{c}{ CP depth to refusal $(\mathrm{mm})$} & \multirow{2}{*}{ Soil moisture (\%) } \\
\cline { 2 - 3 } & 2005 & 2006 & \\
\hline Control NT & 64 & ND & 8.0 \\
Control till & 102 & 165 & 13.2 \\
2000 B & 142 & 163 & 11.5 \\
$2000 \mathrm{C}+\mathrm{B}$ & $\mathrm{ND}$ & 185 & 11.0 \\
$6000 \mathrm{C}$ & 173 & 170 & 11.6 \\
$6000 \mathrm{C}+\mathrm{B}$ & $\mathrm{ND}$ & 185 & 11.7 \\
$6000 \mathrm{WC}$ & $\mathrm{ND}$ & 239 & 15.2 \\
Native & ND & 175 & 12.3 \\
\hline
\end{tabular}


prefer granitic soils rather than volcanic soils. Results from the Tahoma soils boxes, which investigated plant response to different treatments in volcanic and granitic soils indicated slightly higher (though significantly at $>97.5 \%$ level using a students t-test) relative cover by Western needlegrass on granitic soils $(23 \%$ vs. 19\%).] Squirrel-tail was also consistently found in all treatment plots and varied little from treatment to treatment between 5-10\%. Mountain brome was found at a similar range (4-8\%) in the compost plus Biosol plots.

With respect to erosion potential, vegetative cover tends to reduce sediment yields and this was reflected in the results at Northstar as shown in Fig. 3. While both regressions are significant ( $>99 \%$ level), there are few data points and additional investigation is required to determine if the relationships illustrated persist over time.

Soil strength, or compaction conceptually is a function of soil moisture content and should provide an indirect measure of soil infiltration rates or capacity (Nichols and Grismer 1997; Hatchett et al. 2006). RS and cover sampling at Northstar and Heavenly during the summers of 2005-2006 occurred at relatively consistent soil moisture contents of 10 $15 \%$ and $5-7 \%$, respectively. Soil moisture could not readily be related to $\mathrm{CP}$ depth to refusal as summarized in Tables 7 and 8 for example at Northstar. Again, using the Tukey test, plots with the higher levels of compost or woodchips $(6,000 \mathrm{~kg} / \mathrm{ha})$ had significantly greater ( $>95 \%$ level) CP depths as compared to the control plots. Pre-treatment soils at the Heavenly site had high soils densities (small CP depths) relative to native soils, however, posttreatment soils maintained significantly lower soil densities even after 3 years. No trends were found relating $\mathrm{CP}$ depth to refusal and treatment at Heavenly, however, post-rainfall wetting depths indicated that soils with woodchips had greater infiltration capacity as compared to al the other plots. Plots with other amendments had slightly greater wetting depths than the control till plot. Similarly, infiltration rates are generally associated with the higher CP depths, but the relationships based on Tables 7 and 8 data are not significant and require further analyses currently underway.

Soil nutrient levels in the Tahoe Basin soils are generally quite low, particularly in the granitic soils, and are often a limiting factor in plant establishment and growth. Here, we briefly consider the total nitrogen and related organic matter contents of the LT site soils before treatment and three years after treatment (Table 9). At both sites, only four soil samples were collected in 2006. The control till plots had the lowest OM and TKN values, while plots treated with Biosol or Biosol and compost had much higher levels of both organic matter and TKN than the control plot. These levels were also much greater than the average pre-treatment level of organic matter and TKN. Generally, TKN levels were readily correlated with soil OM contents. It should be noted that there was a very large range in both organic matter and
Fig. 3 Dependence of sediment yield on herbaceous cover at the Northstar LT plots

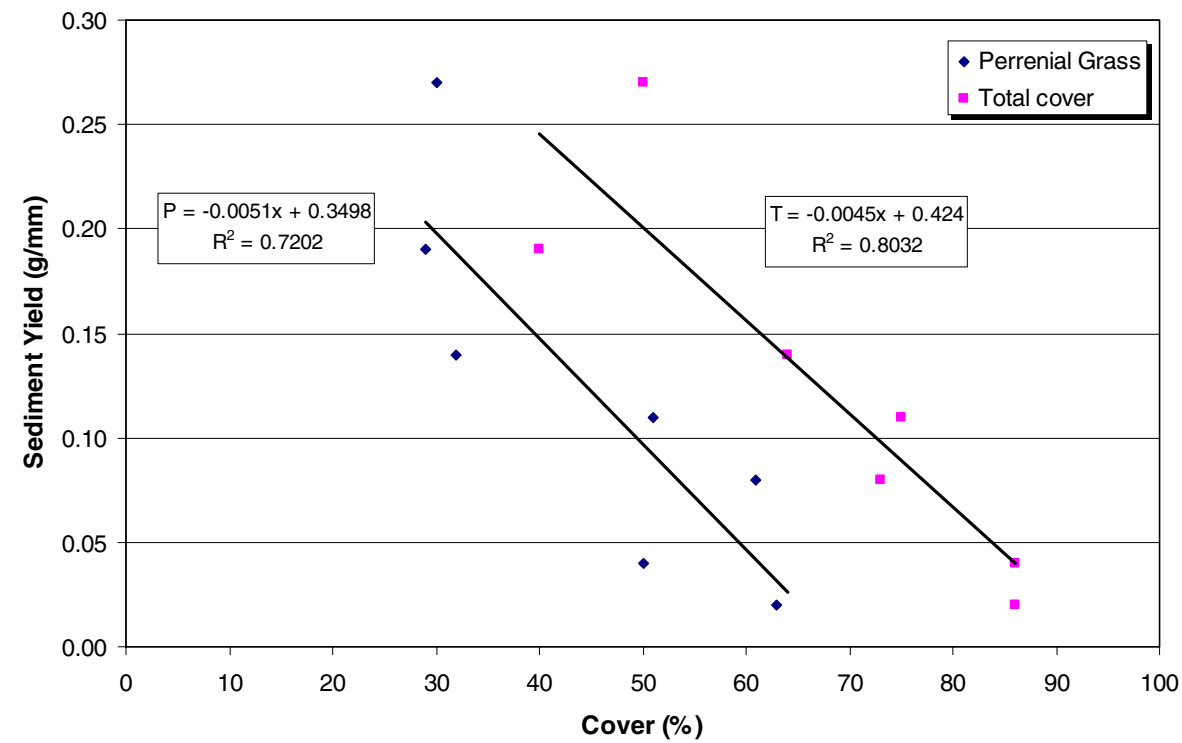


Table 9 Soil organic matter and total nitrogen status before and three years after treatment at Northstar and Heavenly LT sites

\begin{tabular}{llllll}
\hline \multirow{2}{*}{ Treatment } & \multicolumn{2}{l}{ Northstar } & & \multicolumn{2}{l}{ Heavenly } \\
\cline { 2 - 3 } \cline { 6 - 6 } \cline { 6 - 6 } & OM (\%) & TKN (ppm) & & OM (\%) & TKN (ppm) \\
\hline Pre-treatment & 5.5 & 1,100 & & 1.6 & 320 \\
Control till & 3 & 750 & & 1.9 & 730 \\
$2000 \mathrm{~B}$ & 7.6 & 1,700 & & ND & ND \\
$2000 \mathrm{C}+\mathrm{B}$ & $\mathrm{ND}$ & $\mathrm{ND}$ & & 4.0 & 1,400 \\
$6000 \mathrm{C}+\mathrm{B}$ & 7 & 2,350 & & 2.3 & 950 \\
$6000 \mathrm{WC}$ & $\mathrm{ND}$ & $\mathrm{ND}$ & & 1.7 & 800 \\
Native & 5 & 1,600 & & 3.6 & 1,150 \\
\hline
\end{tabular}

TKN in pre-treatment soils, with some of the values falling well below the suggested minimums for supporting higher levels of plant cover. This initial variation may continue to affect levels of $\mathrm{OM}$ and $\mathrm{TKN}$ in the treatment plots.

\section{Results and discussion-overall}

Each of the ten study sites were evaluated in the same manner as that described above for the two LT sites on the two soil types in the basin. Here, we consider the practical integrated monitoring results from all the sites in the contexts of erosion control, soil physical and nutrient conditions and, finally vegetative cover conditions.

\section{Erosion control}

Several sites compared the hydrologic function of untilled, surface treated soils with soils that had been tilled or ripped to between $0.3-0.46 \mathrm{~m}$ (i.e. Brockway Test plots, Brockway Fill Slopes, Meyers Airport, Truckee Bypass, Heavenly LT, Resort at Squaw Creek and Northstar U7). Not surprisingly, RS's showed that tilled or ripped plots, regardless of soil type or site location, had significantly higher infiltration rates than the same soils that were not loosened for as much as three years. During these rainfall simulations, the sediment yield of the tilled, or ripped plots was significantly reduced over that of the unloosened soils. In some cases, the amount of sediment produced on unloosened soils was ten times greater than that from tilled, or ripped soils (e.g. Northstar
U7, Truckee Bypass and Brockway Test plots). In many cases, there was no runoff produced on soils tilled to $0.46 \mathrm{~m}$, even at a rainfall rate of $180 \mathrm{~mm} / \mathrm{h}$ (i.e. Brockway Test plots, Truckee Bypass and Heavenly LT). In general, tilled soils had SYs similar to those of local native sites, while SYs from untilled sites were up to 250 times greater than those from comparable native sites. These sites had different aspects and soil types with slopes between $20^{\circ}$ and $30^{\circ}$ (approximately a 2:1 H/V slope ratio). Otherwise, only plots at Northstar U7, Truckee Bypass and Brockway Test plots that had compost or coarse woody material tilled or ripped into the soil did not yield runoff or sediment. Overall, soils loosened to a depth of at least $0.3 \mathrm{~m}$ and incorporated coarse organic material (woodchips, tub-grindings, composted woodchips or coarse-overs) at a rate of $4,000 \mathrm{~kg} / \mathrm{ha}$ into the soil had the greatest increase in onsite infiltration and the largest reduction in SY over time.

Similarly, several of sites (Brockway Test plots, Truckee Bypass, Meyers Airport, Heavenly LT, Northstar LT and Resort at Squaw Creek) were designed to test the hydrologic function of soils with different types of organic amendments. Organic amendments included partially screened compost, type 1 tub grindings, woodchips, composted woodchips, and coarse-overs, each slightly different. Partially screened compost was the "Integrated Tahoe Blend" from Full Circle Compost in Minden, Nevada and had $25 \%$ fines $(<9.5 \mathrm{~mm})$ and $75 \%$ coarse material (between 9.5 and $76 \mathrm{~mm}$ ). At the Brockway and Truckee bypass test plots, type 1 tub grindings from the Placer county eastern regional landfill were used. Type 1 tub grindings are composed of raw trees, not processed construction wood, and often includes root material and the attached soil, creating a material with higher potential nutrients than plain woodchips. A tub grinder also masticates or shreds the material more than a chipper, creating higher surface area and longer, stringier pieces of organic material. The spear length of the tub grindings was between 25 and $203 \mathrm{~mm}$ and passes through a 152-mm screen. At the Truckee Bypass, Northstar U7 and Northstar LT plots, a composted woodchip material that had aged for 2 years was used in addition to compost and tub grindings. Local woodchips, with an average dimension of $25-50 \mathrm{~mm}$ were used at the Heavenly LT, Resort at Squaw Creek and Meyers Airport sites. At 
the Heavenly LT plots, in addition to compost and woodchips, coarse-overs were used. Coarse-overs, derived from compost by screening, are the large fragments that do not pass through a 9.5 by $9.5 \mathrm{~mm}$ compost screen but will pass a 76 by $76 \mathrm{~mm}$ screen. At the Heavenly LT site, the soils treated with woodchips or coarse-overs yielded minimal runoff during three sampling seasons resulting in lower average SYs than those generated from the native sites. The SY from these plots was up to 60 times less than that from a tilled plot with out any coarse organic material. Plots treated with compost or Biosol had smaller SY than that from plots with no amendments. At the Resort at Squaw Creek, the plots with either woodchips only or a 50-50 mix of woodchips and compost had the lowest SY, about 4-800 times less than the untreated control plots. These treatments also resulted consistently in the greatest infiltration rates $(\sim 120 \mathrm{~mm} / \mathrm{h})$ as compared to about $40 \mathrm{~mm} / \mathrm{hr}$ for the control plots. At the Meyers Airport site, ripping combined with compost had higher infiltration rates and lower average SY than that from ripping mixed with woodchips, though this difference was small. At the Brockway Summit and Truckee Bypass Test sites, plots with incorporated amendments one season after constructed yielded not runoff. Incorporation of woodchips or tub grindings resulted in the greatest wetting depths at those sites where this treatment was employed.

Pine needle mulch (PNM) cover of sufficient depth was an important surface treatment at all sites in terms of reducing runoff and SY's. Potentially, insufficient PNM depths at the LT sites where there has been some downslope movement is less effective and rates of PNM replenishment may need to be considered. Native plots with higher PNM cover and regular replenishment have been shown to have lower SY's (Grismer and Hogan 2004). On disturbed sites with compacted or high density soils, PNM appears to reduce sediment movement through reduced runoff velocities and trapping sediment. Surface mulch alone does not increase infiltration and therefore is not as effective in controlling erosion as soil loosening. For example, at the Truckee Bypass plots, where PNM was applied, but the soil not loosened, the SY's were between 150 and 300 times greater than that produced by tilled soils with surface mulch. Overall, PNM covers of at least $51 \mathrm{~mm}$ was the most effective surface treatment in slowing runoff velocities and trapping sediment movement during the first two growing seasons. This surface mulch was most effective in sites were soil was loosened to a depth of at least $0.3 \mathrm{~m}$. Surface PNM in unloosened soils only delays sediment movement but does not provide increased soil infiltration capacity. Pine needle mulch at sites with high soil densities (smaller CP depths) produced sediment after the soil was saturated by successive precipitation events.

Similar to the PNM, sufficient vegetative cover appears to reduce SY's from all sites. After three growing seasons at the Northstar and Heavenly LT sites, plots with greater than $60 \%$ foliar cover by native perennial species had the lowest SY. On average, these plots had less than half the SY of plots with less than $50 \%$ cover by native perennial species. At Heavenly in 2006, only the control till plots without incorporated organic amendments generated sediment. These plots also had low average perennial plant cover $(\sim 30 \%)$ when compared to the tilled with amendments plots where cover by perennial species of ranged from $35 \%$ to $50 \%$. This is the first year that the relationship between plant cover and infiltration and sediment yield have been more systematically investigated. In the first couple years following disturbance and treatment, PNM appears to be the most effective surface treatment in reducing runoff and SY, however, it seems that successful plant establishment is a more important factor in reducing runoff and SY's over the longer term. Overall, soils loosened to at least $0.3 \mathrm{~m}$ with higher native perennial bunchgrasses covers greater than $50 \%$ were associated with the greatest infiltration rates and lowest SY's after three growing seasons.

\section{Soil characteristics}

Soil physical and nutrient conditions are considered for the treated soils such that direct comparison is made only between volcanic and granitic parent material soils that received successful treatments. Average summer CP depths (aka soil densities) measured at sites with granitic soils ranged from 152-533 mm, while that for the volcanic soil sites was less ranging from 102-229 mm. The CP depths at the Brockway Summit site were an exception as they were constructed in 2005 and may not have settled as much as soils at other volcanic sites installed several years ago. CP depths at Brockway Summit ranged 
from 127-381 mm, depending on the tilling depth. Volcanic soils at the Tahoma Boxes site with either no treatment, or Biosol only, had the shallowest CP depths of about $25 \mathrm{~mm}$, whereas, the other boxes, using different combinations of woodchips, Biosol, and compost had CP depths to refusal of 41$152 \mathrm{~mm}$. Generally, tilled volcanic soil soils consolidate over a few years perhaps as a result of the higher clay content in volcanic soils as compared to the granitic soils. Generally, volcanic soils that were tilled with coarse organic material (woodchips, tub grindings or coarse-overs) maintained lower soil density than the same soils with no amendments or with only Full Circle Integrated Tahoe Blend compost added.

Tillage and addition of amendments generally increased $\mathrm{OM}$ content of the treated soils. Interestingly, at the Meyers Airport site OM contents for ripped soils were slightly lower than that in tilled plots; tilled plot OM contents ranged from 1.6-1.7\%, while that for the ripped plots was $1.2 \%$. At the Heavenly LT site, the control plot, tilled without amendments, had an organic matter content of $1.9 \%$, while the plots amended with coarse-overs had an organic matter content of $4 \%$. Biosol was included in the treatment for this plot, so it may also have had a minor effect on the OM content. However, the OM content for plots with compost and Biosol was only $2.3 \%$, only a slight increase over the control and over most of the pre-treatment OM contents. Similarly, at the Northstar LT site, plots amended with compost and Biosol showed an increase in OM content over that of tilled control plot and pre-treatment $\mathrm{OM}$ values. The $\mathrm{OM}$ content for the plot with compost was $7 \%$, while the tilled control plot had an $\mathrm{OM}$ content of $3 \%$. Overall, soils loosened by tilling, had higher OM contents than plots that were loosened by ripping techniques. Compost and coarse organic material (woodchips, tub grindings, and coarse-overs) also helped to increase OM in the soil.

Addition of compost, woodchips and Biosol affected in the soil TKN contents in all treated soils. Compared to control plots, the addition of compost and Biosol organic fertilizer increased soil TKN levels. For example, at the Northstar LT site, control plots had a TKN of $759 \mathrm{ppm}$, as compared to $1,642 \mathrm{ppm}$ for the Biosol treated plots and 2,353 ppm for plots treated with both Biosol and compost. Similarly, after three years at the Heavenly
LT site, the tilled-only control plots had a lower TKN content (703 ppm) than plots treated with compost or coarse-overs where TKN values ranged from 9291418 ppm. In 2003, at the Resort at Squaw Creek site, plots with a 50-50 combination of compost and woodchips had greater TKN levels than plots with only compost or woodchips added. The same trend was observed again in 2006 as TKN values had even increased in 2006. Overall, it appears that while both compost and Biosol fertilizer increased soil TKN, the combination of compost and woodchips produced higher TKN levels in the soil than either amendment by itself. Finally, this study included only one irrigated site adjacent to a non-irrigated test plot area along the new Truckee Bypass highway. Both the irrigated and non-irrigated plots employed the standard surface treatment (Caltrans Erosion Control Type D). The irrigated plot had the lowest OM and TKN contents when compared to the other test plots, including the control plot without treatment. The TKN at the irrigated plot was $790 \mathrm{ppm}$, while the OM content was $3.1 \%$. All other plots had TKN levels $>1,154 \mathrm{ppm}$ and $\mathrm{OM}$ contents $>4.2 \%$ This TKN level of $<1,000 \mathrm{ppm}$ is well below levels reported for successful long term vegetation establishment within the Tahoe Basin (Claassen and Hogan 2002).

Volcanic soils supported more plant growth as measured by foliar cover and biomass than granitic soils when all other factors were equal. The highest foliar cover measured at the volcanic sites was $95 \%$, while the highest foliar cover at sites with granitic soils was only $50 \%$, perhaps reflecting the very low nutrient levels common to these soils. Mean foliar covers at the Heavenly and Northstar LT sites were $41 \%$ and $56 \%$, respectively. Similarly, at the Tahoma Soil Boxes, above ground biomass from the granitic soil boxes was less than half that collected at the volcanic boxes. Similarly, foliar cover on the granitic boxes was $47 \%$, as compared to $61 \%$ on the volcanic boxes.

\section{Plant cover and composition}

Tillage and incorporation of amendments facilitated plant growth and cover at all sites to varying levels. Two methods of foliar cover estimation are often employed and used here including (a) ocular estimates that may vary by as much as $100 \%$ between different observers (here the same rangeland botanist 
was used for all ocular estimations), and (b) the more defensible and statistically valid plant cover-point method (Elzinga et al. 2001). Typical regulatory success criteria for plant cover are based only on ocular estimates. In this study, ocular estimates of plant cover at the same plots were between $20 \%$ and $35 \%$ higher than plant cover as measured by the cover-point method. At the Brockway and the Truckee Bypass sites, the highest plant cover and cover by native perennial species was on plots amended with compost, rather than tub grindings, or a mix of compost and tub grindings. This difference was greatest at the Truckee Bypass compost plots, where the average total plant cover and native perennial plant cover were $39 \%$ and $31 \%$, respectively. On average, the total cover was $15 \%$ higher than at the plots amended with tub grindings and composted woodchips. The cover by native perennial species in plots with compost was more than two times that of native perennial plant cover in the other plots. The cover by native perennial plants in the compost plots at Truckee Bypass was also higher than native perennial plant cover in the nearby irrigated plots. At the Meyers Airport site and the Tahoma Soil Boxes, this higher cover by native perennial species in plots with compost added had persisted after several growing seasons. In contrast, after one growing season, average cover at all the Truckee Bypass plots was $27 \%$, that at the Brockway Summit plots was $21 \%$, while the compost plots had an average total plant covers of $39 \%$ and $30 \%$, respectively. The woodchip plots at the Brockway Summit plots lacked acceptable amount of first year cover $(5 \%)$. Overall then, first year plant cover in tilled and amended soils without irrigation averaged approximately $25 \%$, while tilling compost into the soil produced the highest cover by desired perennial species in the first two growing seasons. For the purposes of achieving plant cover success criteria set by regulatory agencies, the method of assessment should be taken into account.

After three growing seasons, plots with woodchips, tub grindings, or coarse-overs supported similar native perennial plant cover to that at compost treated plots. At both LT sites, cover by native perennial plant species in plots with coarser woody material was either greater or similar to that of plots with compost. At the Heavenly LT plots, cover at the compost plots was between $40-50 \%$ while that of plots with coarser amendment (coarseovers and woodchips) was between $33 \%$ and $50 \%$. Of these perennial species, a higher proportion was from seeded species in the plots with woodchips and coarse-overs (75\%) as compared to $57 \%$ for the compost plots, suggesting that plots with coarser material sustained the desired seeded species. At the Northstar LT plots, there was no statistical difference in cover by perennial species in plots with different types of amendments, suggesting that any initial advantage compost may provide to the desired perennial species dissipates after 3 growing seasons. This is likely a result of when there is more carbon present in the soil, more of the nitrogen is bound in decomposition of OM. This process occurs within the first growing season. Over time, once some of the OM is digested, soil nitrogen levels rise and may equal or exceed nitrogen levels in plots with compost. On the other hand, higher rates of Biosol organic fertilizer increased cover by weedy annual species but not by desired perennial species. At the Resort at Squaw Creek site, the effects of four different Biosol rates from 2,000 kg/ha to $8,000 \mathrm{~kg} / \mathrm{ha}$ of Biosol on plant cover resulted in significantly increased total cover, however, all of this plant cover was by less-desirable annual species. There was no cover by seeded perennial species. It could be that annual species take advantage of a highly available nitrogen source in the first year of growth more than perennial species.

Plant cover by perennial species was higher in soils tilled with amendments and without irrigation than sites with irrigation and surface amendments but no tilling. The irrigated Truckee Bypass plots using standard Caltrans Erosion Control Type D methods (a surface treatment) with summer-season irrigation resulted in greater cover than any of the non-irrigated tilled plots; however, the majority of this cover $(82 \%)$ was by annual species. The cover by perennial species was only $8 \%$ at the irrigated plots versus between $13 \%$ for tilled plots with composted woodchips, $16 \%$ for plots with tub grindings and 32\% for tilled plots with compost added. The irrigated plot had two growing seasons while the tilled plots without irrigation had only one growing season.

The invasive annual species, cheatgrass (Bromus tectorum), is a problem in many disturbed areas within the Tahoe-Truckee area and throughout California and Nevada. This species became a problem at the Brockway Summit site many years before the 
current test plots were installed. Unfortunately, the cheatgrass seed bank remains within the soils of the test plots. During installation of the test plots, PNM was applied to a depth of $76 \mathrm{~mm}$ and appears to have suppressed the germination rate of cheatgrass seeds in the first growing season following treatment. The plots with woodchips had almost no cheatgrass. It could be that in the woodchip plots, there is less available soil nitrogen, which limited the ability of cheatgrass seeds to germinate. Mulch cover in excess of $50 \mathrm{~mm}$ combined with less initially available nitrogen may have suppressed seed germination and may have been effective in suppressing germination of weedy annual species in the seed bank (i.e. cheatgrass).

An important aspect of the restoration studies considered here is establishment or re-establishment of perennial grasses and forbs at the disturbed soil sites. Mountain brome (Bromus carinatus), a native perennial grass, had higher relative cover in sites with lower solar exposure and/or higher soil nutrient levels. Our study sites and a similar study conducted for Placer County in Kings Beach showed that at shaded sites (20-60\% solar exposure) and/or sites with higher levels of soil nitrogen, both the total cover by mountain brome, and the proportion of cover by mountain brome was dominant. At the Truckee Bypass site, cover by mountain brome was highest in the compost plots, $20 \%$ as compared to $10-12 \%$ for soils treated with composted woodchips and tub grindings, respectively. The compost treated plots had the highest TKN, and due to the lower woody material, the lowest $\mathrm{C}: \mathrm{N}$ ratio. Mountain brome is one of the faster growing bunchgrasses in the TahoeTruckee area and is known to prefer moist sites with deeper soils (Tollefson 2006). Because it is a faster growing plant, it can initially utilize higher amounts of soil nitrogen, which may be why higher relative cover of this species have been observed on compost amended plots.

Similarly, squirreltail (Elymus elymoides) represented a significant amount of cover at each site where it was seeded. It is also a common native species occurring at many drier sites within the Tahoe-Truckee area as it has a high drought tolerance. It has been recommended as an erosion control species on "harsh sites" within the Tahoe basin (Chistopherson and Johnson 2006). It occurs naturally on shallow, stony, or gravelly soils with low nutrient status (Simon et al. 2003). At many disturbed areas, such as road cuts, native top soil is removed. The remaining subsoil is often rocky with low soil nutrient levels. These conditions may be similar to native soil conditions where squirreltail is found. It also may be that when soil nutrient levels are increased through amendments and Biosol, this species persists; thus it may be able to adapt well to higher nutrient levels. This species may be the most "elastic" species in the local area as it has been shown to establish and persist in many different soil conditions. It is not as abundant in moister more shaded areas. Squirreltail, a native perennial grass, was the most ubiquitous grass species regardless of treatment, soil type, and/or solar exposure.

Western needlegrass, a native perennial grass, represented a higher proportion of plant cover on sites with lower total soil nutrients and/or high solar exposure. Western needlegrass was did not represent a high proportion of cover at most sites, where it was included in the seed mix. The exception was at the Heavenly LT site, where it was the most common species and was the dominant cover in most plots. This site has high solar exposure and granitic soil that is low in available nutrients. At the Heavenly site, plots with coarse-overs and woodchips had on average $20 \%$ cover by western needlegrass, or about $67 \%$ of the cover by seeded species. In the plots with compost or compost and Biosol, cover by western needlegrass was only $10 \%$, or about $50 \%$ of the cover by seeded species. Archer (2000) reported that needlegrasses (Achnatherum species) are generally tolerant of high sunlight and persist in drought conditions and often occur on dry sites with stony soils. Needlegrasses have been seeded at mine reclamation sites throughout the western states, in soils with low nutrient levels (Richardson 1985). Results at the Tahoma soil boxes also suggest that this species prefers granitic soils and soils with lower available nutrients. Western needlegrass represented a higher proportion of the total cover in granitic soils than in volcanic soils. Within the granitic soils, the control box with no added nutrients, and the box with Biosol only, had the highest cover by western needlegrass in 2006, after three growing seasons when the nitrogen available from Biosol was significantly depleted. The highest cover by western needlegrass in the volcanic soils was found in the control box with no added nutrients. It could be that 
western needlegrass is a slower growing species that does not benefit from higher nutrient inputs and can not compete with species like squirreltail and mountain brome when higher levels of available nutrients are present.

\section{Summary and conclusions}

In this integrated monitoring analysis we consider results from more than 120 plots and a 3-year period across the Tahoe Basin. The integrated analysis allowed initial quantification of the effects of specific soil and vegetative treatments on disturbed soils in the region. This is the first major attempt in the Tahoe Basin to lend credible and real-time data results to the discussion of how to reduce/minimize sediment production from these types of disturbed sites. Not only will this information enable land managers to determine appropriate and cost effective treatments, it enables designers and implementers to improve existing treatments based on actual knowledge of how well current treatments perform. Generally, incorporated treatments out perform surface treatments and have a longer lasting effect on plant densities and erosion control. While longer-term duration studies are required, it appears that incorporated treatments adding woodchips and/or compost may place disturbed soils on a trajectory towards conditions found in the "native" sites. Future treatments can then be compared with data from existing treatments. This is the essential foundation of an effective technology improvement program. The overall results can be summarized as follows.

1. Restoration methods that loosened the soil to at least $0.3 \mathrm{~m}$, rather than simply surface treatments that do not loosen the soil had the greatest increase in onsite infiltration and the largest decrease in sediment yield.

2. In soils loosened to a depth of at least $0.3 \mathrm{~m}$, restoration methods that incorporated coarse organic material (woodchips, tub-grindings, composted woodchips or coarse-overs) at a rate of $\sim 4,000 \mathrm{~kg} / \mathrm{ha}$ into the soil had the greatest increase in onsite infiltration and the largest reduction in sediment yield over time.

3. Ground mulch of at least $51 \mathrm{~mm}$ of native pine needle mulch was the most effective surface treatment in slowing runoff velocities and trapping sediment movement during the first two growing seasons. This surface mulch was most effective at sites where soil was loosened to a depth of at least $0.3 \mathrm{~m}$. Surface pine needle mulch in unloosened soils only delays sediment movement; it does not increase soil infiltration capacity. PNM at sites with high soil density produced sediment after the soil was saturated by successive precipitation events.

4. In soils loosened to at least 12 in. $(30.5 \mathrm{~cm})$, higher cover by native perennial bunchgrasses was associated with higher infiltration rates and lower sediment yields after three growing seasons.

5. Under the same treatment conditions, granitic soils maintained a lower soil density over time than volcanic soils, which naturally have a higher proportion of fine clay particles per unit volume.

6. Volcanic soils supported more plant growth as measured by biomass and foliar cover than granitic soils when all other factors were equal.

7. Soils derived from volcanic parent material that were tilled with coarse organic material (woodchips, tub grindings or coarse-overs) maintained lower soil density than the same soils with no amendments or with only compost added.

8. Both compost and Biosol fertilizer increased soil TKN levels, while compost and coarse organic material (woodchips, tub grindings, and coarseovers) increased soil OM.

9. The combination of compost and woodchips produced higher TKN levels in the soil than either amendment by itself.

10. Plots, in which the soil was loosened by tilling, had higher OM contents than plots that were loosened by ripping techniques.

11. Irrigated plots with surface treatment only had the lowest soil TKN and OM levels, levels below that reported necessary to sustain adequate plant growth.

12. Tilling compost into the soil produced the highest cover by desired perennial species in the first two growing seasons.

13. Over time (3 years), plots with woodchips, tub grindings, or coarse-overs supported similar native perennial plant cover to the plots with compost. 
14. Higher rates of Biosol increased cover by weedy annual species, but not by desired perennial species.

15. In tilled soils with Biosol, seed, and amendments (compost, tub grindings, coarse-overs, or woodchips), total plant cover in the first growing season, without irrigation, was between $15 \%$ and $35 \%$.

16. Mulch cover in excess of at least $51 \mathrm{~mm}$, combined with less initially available nitrogen may have suppressed seed germination and may have been effective in suppressing germination of weedy species in the seed bank (i.e. cheatgrass).

17. Plant cover by native perennial species was higher in tilled soils with amendments and without irrigation than sites with irrigation and surface amendments but without tilling.

18. Favorable native perennial grass species flourished under different conditions. Mountain brome had higher relative cover in sites with lower solar exposure and/or higher soil nutrient levels. Squirreltail was the most ubiquitous grass species regardless of treatment, soil type and/or solar exposure. Western needlegrass represented a higher proportion of plant cover on sites with lower total soil nutrients and/or high solar exposure.

\section{References}

Archer, A. J. (2000). Achnatherum thurberianum. In Fire effects information system. U.S. Department of Agriculture, Forest Service, Rocky Mountain Research Station, Fire Sciences Laboratory. http://www.fs.fed.us/database/feis/.

Caltrans (2007). Monitoring and assessment of erosion control treatments in and around the Lake Tahoe Basin. Final Report. 211 p.

Chistopherson, J., Johnson, W. S. (2006) Turf and erosion control grasses for the Tahoe Basin. University of Nevada, Reno Cooperative Extension (available online).

Claassen, V., \& Hogan, M. (2002). Soil nitrogen pools associated with revegetation of disturbed sites in the Lake Tahoe area. Restoration Ecology, 10(2), 195-203.

Claassen, V. P., \& Zasoski, R. J. (1998). A comparison of plant available nutrients on decomposed granite cut slopes and adjacent natural soils. Land Degradation \& Development, 9(1), 35-46.

Cummings, J. (2003). Using process-oriented parameters to assess degradation. Ecological Management and Restoration 4: S79-S82.

Ellis, A. L. (2006). Erosion Sediment Analysis of Disturbed Soils in the Lake Tahoe Basin. Soils \& Biogeochemistry MS Thesis, UC Davis.
Elzinga, C. L., Salzer, D. W., Willoughby, J. W., \& Gibbs, J. P. (2001). Monitoring plant and animal populations. Malden, MA: Blackwell Science.

Fifield, J. S., \& Malnor, L. K. (1990). Erosion control materials vs. a seimarid environment - What has been learned from three years of testing? Proc. Int'l Erosion Control Assoc. Conference XXI. pp. 233-248.

Fifield, J. S., Malnor, L. K., \& Dezman, L. E. (1989). Effectiveness of erosion control products on steep slopes to control sediment and to establish dry land grasses. Proc. Int'1 Erosion Control Assoc. Conference XX. 10 pages.

Fifield, J. S., Malnor, L. K., Richter, B., \& Dezman, L. E. (1988). Field testing of erosion control products to control sediment and to establish dry land grass under arid conditions. Proc. Int'l Erosion Control Assoc. Conference XIX. 17 pages.

Foltz, R. B., \& Copeland, N. S. (2008). Evaluating the efficacy of wood shreds for use in erosion mitigation. Journal of Environmental Management (in press).

Goldsmith, W. (2006). Soil strength reinforcement by plants. International Erosion Control Web Site: http://www.ieca. org/membersonly/resources/proceedings/2006/.

Grismer, M. E. (2007). Soil restoration and erosion control: Quantitative assessment in rangeland and forested areas. ASABE Transactions Soil \& Water Centennial Collection, 50(5), 1619-1626.

Grismer, M. E., \& Ellis, A. L. (2006). Sediment particle-size distributions in runoff from disturbed soils in the Lake Tahoe Basin. California Agriculture, 60(2), 72-76.

Grismer, M. E., Ellis, A. L., \& Fristensky, A. (2007). Runoff sediment particle-sizes associated with soil erosion in the Lake Tahoe Basin. Land Degradation \& Development, 18, $1-20$.

Grismer, M. E., \& Hogan, M. P. (2004). Evaluation of revegetation/mulch erosion control using simulated rainfall in the Lake Tahoe Basin: 1. Method assessment. Land Degradation \& Development, 13, 573-588.

Grismer, M. E., \& Hogan, M. P. (2005a). Evaluation of revegetation/mulch erosion control using simulated rainfall in the Lake Tahoe Basin: 2. Bare soil assessment. Land Degradation \& Development, 16, 397-404.

Grismer, M. E., \& Hogan, M. P. (2005b). Evaluation of revegetation/mulch erosion control using simulated rainfall in the Lake Tahoe Basin: 3. Treatment assessment. Land Degradation \& Development, 16, 489-501.

Hatchett, B., Hogan, M. P., \& Grismer, M. E. (2006). Mechanized mastication effects on soil compaction and runoff from forests in the Western Lake Tahoe Basin. California Agriculture, 60(2), 77-82.

Hogan, M. (2003). Luther pass monitoring report: Plant and soil cover monitoring for evaluating sediment source control success in the Lake Tahoe Basin. South Lake Tahoe, CA: Lahontan Regional Water Quality Control Board.

Montoro, J. A., Rogel, J. A., Querejeta, J., Diaz, E., \& Castillo, V. (2000). Three hydro-seeding revegetation techniques for soil erosion control on anthropic steep slopes. Land Degradation \& Development, 11, 315-325.

Nichols, J. R., \& Grismer, M. E. (1997). Measurement of fracture mechanics parameters in silty-clay soils. Soil Science, 162(5), 309-322. 
Poulenard, J., Podwojewski, P., Janeau, J.-L., \& Collinet, J. (2001). Runoff and soil erosion under rainfall simulation of Andisols from the Ecuadorian Paramo: effect of tillage and burning. Catena, 45, 185-207.

Richardson, B. Z. (1985). Reclamation in the intermountain rocky mountain region. In M. K. McCarter (Ed.), Design of non-impounding mine waste dumps (pp. 177-192). New York: American Institute of Mining, Metallurgical, and Petroleum Engineers.

Schuster, S., \& Grismer, M. E. (2004). Evaluation of Water Quality Projects in the Lake Tahoe Basin. Environmental Monitoring and Assessment, 90, 225-242.

Simon, A., Langendoen, E., Bingner, R., Wells, R., Heins, A., Jokay, N., et al. (2003). Lake Tahoe Basin framework implementation study: Sediment loadings and channel erosion. USDA-ARS, Channel and Watershed Processes Research Unit, National Sedimentation Laboratory, Oxford. MI.

Tollefson, J. E. (2006). Bromus carinatus. In Fire effects information system. U.S. Department of Agriculture, Forest Service, Rocky Mountain Research Station, Fire Sciences Laboratory (Producer). Retrieved from http:// www.fs.fed.us/database/feis/.

White, C. A., \& Franks, A. L. (1978). Demonstration of erosion and sediment control technology: Lake Tahoe Region of CA. Municipal Environment Research Lab, Office of Research \& Development. USEPA Demonstration Grant No. S803181, Cincinnati, OH. 